\title{
SOSIALISASI PEMBELAJARAN INOVATIF MELALUI PERMAINAN HITBALL PADA PEMBELAJARAN PENDIDIKAN JASMANI SEKOLAH DASAR
}

\author{
Roas Irsyada $^{1 *}$, Sulaiman', Bambang Priyono ${ }^{1}$, Agus Widodo Suripto ${ }^{1}$ \\ ${ }^{1}$ Pendidikan Jasmani, Kesehatan, dan Rekreasi, Fakultas Ilmu Keolahragaan, Universitas Negeri Semarang, \\ Semarang, Indonesia \\ *Penulis Korespondensi: roaspjkr@mail.unnes.ac.id
}

\begin{abstract}
Abstrak
Salah satu materi dalam penjasorkes adalah permainan bola kecil yang penerapannya di sekolah masih kurang maksimal karena siswa kurang aktif dan kesulitan menguasai teknik dasar dengan baik. Dengan tidak maksimalnya pembelajaran yang dilakukan maka akan menganggu proses pencapaian tujuan pembelajaran. Perlunya informasi kepada guru penjas tentang bentuk modifikasi permainan bola kecil yang inovatif. Informasi tersebut diberikan melalui kegiatan sosialisasi permainan Hitball dengan metode yang digunakan adalah demonstrasi. Kegiatan ini diikuti oleh siswa kelas 5 pada beberapa sekolah dasar di Kecamatan Gunungpati Semarang. Melalui penerapan permainan Hitball pada pembelajaran penjas, siswa sangat aktif dan antusias dalam melakukan permainan. Hal ini sesuai dengan tujuan pembelajaran penjas untuk menggerakkan siswa. Melalui sosialisasi permainan inovatif hitball juga memberikan gambaran kepada guru penjas terhadap bentuk modifikasi permainan bola kecil.
\end{abstract}

Kata Kunci : Permainan Bola Kecil, Pendidikan Jasmani.

\begin{abstract}
One of the material in penjasorkes is a small ball game whose application in school is still not optimal because students are less active and have difficulty mastering basic techniques well. With no maximum learning done it will disrupt the process of achieving learning objectives. The need for information to $P E$ teachers about innovative small ball game modifications. This information is provided through the socialization of Hitball games with the method used is demonstration. This activity was attended by 5th graders of elementary school in Gunungpati District, Semarang. Through the application of Hitball games in PE learning, students are very active and enthusiastic in playing the game. This is in accordance with the learning objectives of Penjas to move students. Through socialization of the innovative game Hitball also provides an overview to the physical education teacher about the form of small ball game modifications.
\end{abstract}

Keywords: Small Ball Games, Physical Education.

\section{PENDAHULUAN}

Penjasorkes merupakan bagian integral dari proses pendidikan secara keseluruhan, dimana bidang studi Penjasorkes di sekolah mempunyai peran unik dibanding bidang studi lain, adapun peran unik itu diantaranya : 1) meletakkan dasar karakter yang kuat melalui internalisasi nilai dalam pendidikan jasmani, 2) membangun landasan kepribadian yang kuat, sikap cinta damai, sikap sosial, toleransi dalam konteks kemajemukan budaya, etnis dan agama, 3) mengembangkan sikap sportif, jujur, disiplin, bertanggungjawab, kerjasama, percaya diri, dan demokratis, 4) mengembangkan keterampilan gerak dan keterampilan teknik serta strategi berbagai permainan dan olahraga, aktivitas pengembangan, senam, aktivitas ritmik, akuatik (aktivitas air), pendidikan luar sekolah (outdoor education), 5) mengetahui dan memahami konsep aktivitas jasmani sebagai informasi untuk mencapai kesehatan, kebugaran, dan pola hidup sehat. Untuk mewujudkan tujuan Penjasorkes di atas, maka lingkungan pembelajaran Penjasorkes harus di atur secara seksama untuk meningkatkan pertumbuhan dan perkembangan seluruh ranah, jasmani, psikomotor, kognitif, dan afektif setiap siswa secara seimbang (Samsudin, 2008).

Pengembangan ranah pembelajaran penjasorkes tidak terlepas dari ruang lingkup materi pembelajaran yang diajarkan dengan tujuan mengenalkan dan meningkatkan ketrampilan gerak melalui proses belajar gerak. Belajar gerak merupakan proses penyempurnaan gerak melalui latihan dan pengalaman gerak (Amung, 2000). Proses belajar gerak yaitu dengan cara memahami gerakan dan melakukan gerakan berulangulang yang disertai dengan kesadaran fikir akan benar atau tidaknya gerakan yang telah dilakukan guan 
meningkatkan ketrampilan gerak. Keterampilan gerak adalah kemampuan untuk melakukan gerakan secara efektif dan efisien. Keterampilan gerak merupakan perwujudan dari kualitas koordinasi dan kontrol atas bagian-bagian tubuh yang terlibat dalam gerakan. Ketrampilan gerak dapat dilakukan menggunakan media gerak berupa olahraga.

Media gerak berupa olahraga adalah setiap akrivitas fisik berupa permainan yang dilakukan dalam bentuk pertandingan, baik melawan unsur-unsur alam, orang lain, maupun diri sendiri (Abdulkadir, 1992). Pendidikan jasmani di sekolah memberi kesempatan kepada siswa untuk terlibat secara langsung dalam aneka pengalaman belajar melalui aktifitas jasmani, bermain, dan aktifitas olahraga secara sistematik, dan terarah sebagai media untuk meningkatkan kemampuan melalui media gerak berupa materi-materi dalam ruang lingkup pembelajaran penjasorkes.

Permainan bola kecil merupakan salah satu materi pembelajaran penjasorkes yang diajarkan di Sekolah Dasar. Sesuai dengan kompetensi dasar pada materi permainan bola kecil pada kelas atas, disebutkan bahwa siswa dapat mempraktikkan teknik dasar permainan bola kecil dengan peraturan yang dimodifikasi untuk memupuk kerjasama, sportifitas dan kejujuran. Melalui permainan bola kecil diharapkan timbulnya intensitas gerak siswa yang lebih aktif dan tercapainya Kompetensi Dasar yang diharapkan. Pelaksanaan pembelajaran Pendidikan Jasmani merupakan aneka kegiatan jasmani yang mendorong siswa untuk berlatih dan mengeksplorasi. Oleh karena itu aktivitas jasmani perlu disajikan secara sistematis, melibatkan semua, dan menggembirakan (Rusli, 2001). Dalam pelaksanannya pendidikan jasmani melalui permainan bola kecil belum efektif sebagai media pembelajaran gerak. Materi pembelajaran permainan bola kecil belum mampu membuat anak bergerak secara efektif. Keadaan ini berakibat pada terbatasnya waktu anak dalam bergerak, sehingga pembelajaran gerak tidak optimal. Selain itu proses pembelajaran permainan bola kecil di temui beberapa hal antara lain:

1. Alat dan media belajar yang di gunakan minim. Sebagaimana peran media pembelajaran merupakan penyalur pesan berupa materi yang ingin diteruskan kepada sasaran pembelajaran (Muhson, 2010) dan media dapat meningkatkan motivasi belajar siswa (Suliska, 2014).

2. Siswa tidak aktif mengikuti pembelajaran.

3. Teknik dasar memukul bola sebagai awal permainan yang belum dikuasai oleh siswa sehingga permainan tidak dapat berjalan optimal.

4. Pembelajaran permainan bola kecil yang diberikan oleh guru masih belum dikemas dalam bentuk modifikasi, sehingga dijumpai siswa yang merasa bosan dan tidak bergerak secara efektif.

Berdasarkan hasil observasi tentang fakta proses pembelajaran Pendidikan Jasmani materi permainan bola kecil di Kecamatan Gunungpati, didapatkan beberapa permasalahan mitra diantaranya adalah :
1) Pembelajaran penjasorkes khususnya permainan bola kecil yang belum efektif. Ditinjau dari kurangnya intensitas gerak siswa saat permainan bola kecil karena teknik memukul sebagai awalan permainan tidak dapat dikuasai oleh semua siswa.

2) Kurangnya kemampuan guru dalam mengembangkan dan memodifikasi pembelajaran dengan kondisi keterbatasan sekolah dalam memenuhi sarana dan prasarana yang memadahi untuk proses pembelajaran penjas pada umumnya, dan permainan bola kecil pada khususnya.

Guna mewujudkan pembelajaran gerak yang optimal, maka peran guru sebagai fasilitator dalam pembelajaran sangat penting karena dituntut dapat mengelola siswa dan memberikan pembelajaran yang inovatif. Bentuk pembelajaran inovatif dalam permainan bola kecil salah satunya adalah dengan memodifikasi permainan dari segi peralatan dan peraturannya. Permainan Hitball adalah sebuah modifikasi bentuk permainan bola kecil yang efektif dan sudah dibuktikan melalui proses pengembangan sebelumnya. Pengenalan permainan Hitball bertujuan memberikan bentuk permainan inovatif guna mempermudah siswa dalam menguasai Kompetensi Dasar yang ditentukan. Selain itu, sosialisasi dan pengenalan permainan hitball kepada para guru penjas dan siswa agar menjadi referensi pembelajaran bola kecil yang inovatif agar tercipta pembelajaran yang menyenangkan.

Berdasarkan analisis kebutuhan, maka perlunya diadakan sosialisasi tentang pembelajaran inovatif tentang bentuk modifikasi permainan bola kecil bagi siswa sekolah dasar.

\section{METODE}

Dalam rangka merealisasikan program kegiatan pengabdian dengan nyata dan terlaksana dengan optimal, maka pelaksanaan program pengabdian akan dilaksanakan dengan mengadopsi langkah-langkah action research yang terdiri dari 4 (empat) tahapan, yaitu: perencanaan, tindakan, observasi dan evaluasi, dan refleksi. Kegiatan-kegiatan atau aktivitas-aktivitas dari masing-masing tahapan adalah sebagai berikut:

\section{Perencanaan}

Kegiatan-kegiatan yang dilakukan pada tahap perencanaan adalah (1) Melakukan koordinasi dengan UPTD Pendidikan kecamatan Gunungpati dengan menjelaskan rencana program kegiatan pengabdian dan menyampaikan izin melaksanakan program pengabdian di sekolah dasar yang ada di kecamatan Gunungpati. (2) Penentuan lokasi sekolah dasar tempat pelaksanaan pengabdian yang disesuaikan dengan karakteristik dan kondisi sekolah, jarak tempuh tim pengabdi, dan dana yang telah disediakan. (3) Sebelum dilakukan program kegiatan bagi siswa akan diberikan sosialisasi program kegiatan pengabdian kepada guru dan siswa. (4) Penyusunan program pelatihan, berdasarkan hasil identifikasi, hasil analisis permasalahan yang ada dan hasil analisis kebutuhan, selanjutnya disusun program sosialisasi permainan Hitball. Hal tersebut dilakukan 
agar pemberian program kegiatan pengabdian tersusun dan terencanan secara sistematis dan tepat.

\section{Tindakan}

Tindakan dalam kegiatan ini berupa implementasi program. Kegiatan-kegiatan yang dilakukan dalam implementasi program adalah Pemberian program pelatihan sosialisasi permainan bola kecil sebagai program prioritas yang diupayakan untuk mengatasi permasalahan mitra akan dilaksanakan dalam 2 kali pertemuan di sekolah dengan tatap muka selama 90 menit.

\section{Observasi dan Evaluasi}

Observasi dilakukan terhadap keseluruhan proses program kegiatan pelatihan dan pendampingan terhadap siswa. Instrumen yang digunakan berupa catatan lapangan, dokumentasi, dan panduan atau modul. Beberapa hal yang diobservasi adalah kendala-kendala, kekurangan-kekurangan, dan kelemahan-kelemahan yang muncul dalam proses pelaksanaan kegiatan di lapangan maupun dalam proses pelaksanaan kegiatan di kelas. Evaluasi dilakukan terhadap kuantitas dan kualitas pelaksanaan program.

\section{Refleksi}

Refleksi dilakukan terhadap kegiatan yang telah dilaksanakan. Hal ini dilakukan semata-mata untuk mengetahui kekurangan atau kelebihan-kelebihan terhadap kegiatan-kegiatan yang telah dilakukan dalam rangka untuk menetapkan rekomendasi terhadap keberlangsungan atau pengembangan kegiatan-kegiatan berikutnya. Kegiatan Pengabdian dini berupa sosialisasi permainan Hitball sebagai bentuk modifikasi inovatif dari permainan bola kecil. Metode yang digunakan yaitu demonstrasi dan siswa kemudian melakukan permainan hitball.

\section{HASIL DAN PEMBAHASAN}

Kegiatan Pengabdian kepada Masyarakat tentang Sosialisasi permainan inovatif Hitball dapat menunjukkan kesuaian antara hasil dengan tujuan kegiatan Pengabdian Masyarakat, yaitu siswa dan guru mengenal bentuk pembelajaran inovatif tentang permainan bola kecil guna membantu siswa dalam mencapai Kompetensi Dasar yang diharapkan. Pembelajaran permainan bola kecil yang awalnya bersifat monoton dan membosankan karena hanya permainan kasti yang sering diberikan guru, sekarang menjadi menjadi lebih menyenangkan dan siswa berperan aktif antusias dalam melakukan permainan. Pembelajaran penjas tidak dijumpai siswa yang merasa enggan bergerak. Melalui sosialisasi pengenalan Hitball siswa dan guru mengenal bentuk baru pengembangan permainan bola kecil. Pelaksanaan pembelajaran diawali didalam kelas dengan penjelasan tujuan pembelajaran dan pengenalan alat kepada siswa. Selanjutnya pembelajaran dilakukan di lapangan dengan memperagakan permainan Hitball. Hasil dari pembelajaran permainan bola kecil menjadi lebih menarik. Selain itu penguasaan teknik dasar lebih mudah dilakukan oleh siswa. Siswa dapat melakukan teknik dasar menangkap, melempar, dan memukul bola dengan baik dan benar. Hal ini sesuai dengan kompetensi yang diharapkan pada ruang lingkup permainan dan olahraga, khususnya permainan bola kecil.

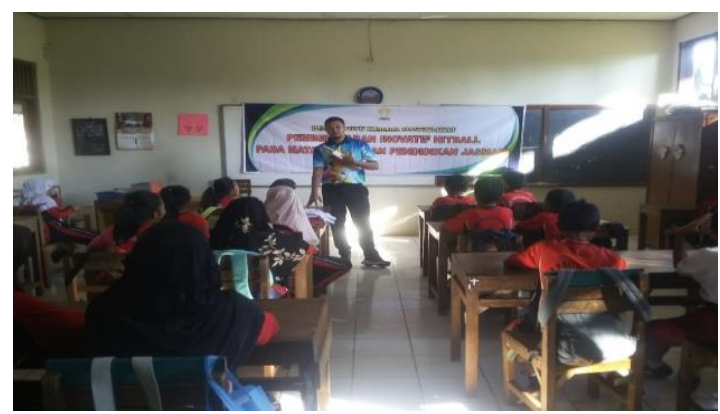

Gambar 1. Pengenalan Alat Dan Penjelasan Awal Di Ruang Kelas.

Terbentuknya permainan ini berawal dari masalah saat permainan bola kecil siswa mengalami kesulitan menguasai teknik memukul bola sebagai dimulainya sebuah permainan. Hal ini berakibat ada terganggunya proses pembelajaran penjas. permainan bola kecil yang menggunakan teknik dasar lempar, tangkap, dan memukul bola awalnya terasa membosankan karena permainan tidak berjalan maksimal. Tidak maksimalnya permainan dikarenakan siswa tidak dapat menguasai teknik dasar memukul sehingga bola tidak dapat terpukul. Dengan adanya tiang penyangga bola, dan bola diam mejadi lebih mudah untuk dipukul. Melalui pembelajaran inovatif permainan Hitball siswa dan guru mendapatkan informasi tentang bentuk modifikasi permainan bola kecil. Hasil kegiatan pengabdian kepada masyarakat ini sesuai dengan tujuan penelitian pengembangan modifikasi permainan bola kecil ini, yaitu mencipatakan pemblajaran yang menyenangkan pada pembelajaran pendidikan jasmani pada materi pembelajaran bola kecil.

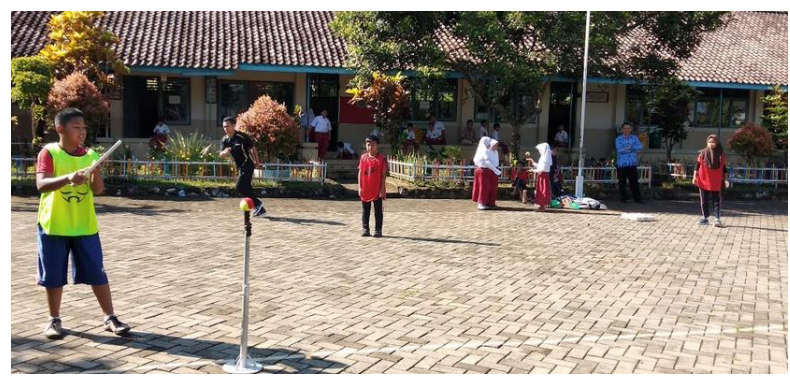

Gambar 2. Siswa Bersiap Melakukan Pukulan Pada Permainan Hitball.

\section{KESIMPULAN}

Kegiatan pengabdian kepada masyarakat memberikan manfaat kepada siswa yaitu dengan meningkatnya kemampuan siswa dalam menguasai teknik dasar pada permainan bola kecil seperti melempar, menangkap, dan memukul bola. Selain itu, siswa menjadi lebih aktif dan antusias dalam pembelajaran permainan bola kecil. Pembelajaran inovatif Hitball memberikan gambaran kepada guru penjas tentang bentuk modifikasi 
permainan bola kecil. Melalui sosilisasi ini diharapkan dapat menjadi referensi kepada guru penjas pada inovasi pembelajaran penjas selanjutnya.

\section{DAFTAR PUSTAKA}

Ali Muhson. (2010). Pengembangan Media Pembelajaran Berbasis Teknologi Informasi. Jurnal Pendidikan Akuntansi Indonesia, 8 (2).

Abdulkadir Ateng. (1992). Asas Dan Landasan Pendidikan Jasmani. Departemen Pendidikan Dan Kebudayaan Direktorat Jenderal Pendidikan Tinggi.

Amung. (2000). Perkembangan gerak dan belajar gerak. Jakarta: DEPDIKBUD.

Rusli, L. (2001). Asas-asas Pendidikan Jasmani.Bandung: FPOK UPI.

Samsudin, (2008). Pembelajaran Pendidikan Jasmani Olahraga dan Kesehatan SD/MI. Jakarta: Litera.

Suliska. (2014). Survei Pemanfaatan Media Pembelajaran Pada Mata Pelajaran Penjasorkes SD Negeri Se Kecamatan Lasem Kabupaten Rembang Tahun 2013. Journal of Physical Education, Sport, Health and Recreations Active 3 (10). 